\title{
The experiences of African Roman Catholic Church seminarians
}

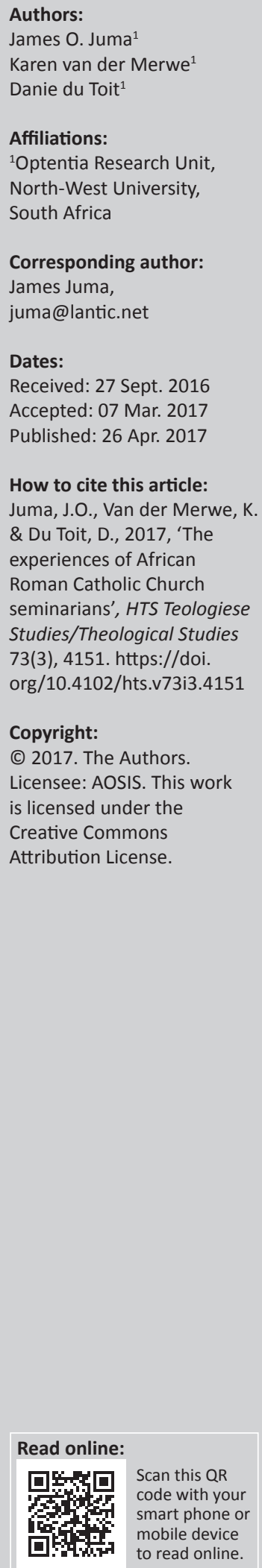

This qualitative study describes and interprets the lived experiences of African Roman Catholic Church seminarians (priests-in-training). The interpretive lens employed was world view, a conceptual tool extensively used in African-centred psychology. Sixteen African seminarians (age range 21-31 years) were purposely selected and interviewed in depth. Additional sources of data were reflexive notes and observation notes. Data were subjected to various iterative cycles of analysis. Participants described their difficulty in adjusting in the seminaries where teaching and living predominantly reflects a Western world view. They evidenced cognitive dissonance, emotional discomfort and feelings of marginalisation. The findings point to the importance of acknowledging the world views and cultural heritage of seminarians in their training.

\section{Introduction}

In this article, the well-documented differences in the African and Western world views (Carroll 2012; Magesa 2013b; Nsamenang 2007) are empirically explored in relation to the experiences of African Roman Catholic Church (RCC) priests-in-training (seminarians) immersed in a predominantly Western-oriented system and are examined, described and interpreted in terms of African world views thus situating the study within African-centred psychology (Kwate 2005). Following the approach of Carroll (2014), the concepts of world view and culture will be used as analytical tools of exploration and analysis. We argue that should the differences between African and Western world views (as represented by the RCC) be ignored in the training of seminarians, it may impact the psychosocial and spiritual well-being and development of seminarians. It is acknowledged that the RCC training certainly is as challenging for Westerners as it is for Africans. However, Africans' difficulties seem to have a specific character because of their culture. This article aims to highlight the distinctive experiences and challenges of African priests in training as they learn and live in a foreign world view and culture and to propose possibilities to facilitate their adjustment to the religious-spiritual life they have committed themselves to.

According to the Report of the Centre for the Study of Global Christianity (CSGC 2013:14), Roman Catholics form the largest bloc of Christians in Africa. Between 1970 and 2010, the Roman Catholic member numbers increased from 44.9 million to 197 million. A further increase in RCC members was projected, which will require more African RCC priests. The task of preparing men for service in the RCC is fulfilled by RCC seminaries, and the purpose of the RCC seminary training is to form men spiritually, academically and pastorally (Comm 14 182:160). Future priests as leaders of their Christian communities need to learn to be flexible, adaptive and proactive in dealing with issues of their community members (Can 232-264; Corieden, Green \& Heintschel 1985; Magesa 2013a:86-87).

The African world view will be described next, and thereafter, the main values to be cultivated in seminarians during their training such as cherishing community life, celibacy, poverty and obedience (Ellis 1965) will be critically discussed in the context of the African world view.

\section{African world view}

The concept world view is widely used in African-centred psychology (Jamison \& Carroll 2014; Mazama 2001; Myers 1988) as a conceptual tool to highlight philosophical distinctions between African and Western cultures. An African world view is described as follows (Makwe 1985):

a psychological reality referring to shared constructs, shared patterns of belief, feeling and knowledge which members of the group that subscribe to this reality carry in their minds as a guide for conduct and the definition of reality. (p. 4) 
An African world view is characterised by its distinct cosmology, epistemology and axiology (Mazama 2001:393; Rowe 2016:270).

\section{Cosmology - Assumptions regarding the structure of the universe}

One could argue that the leitmotif in African cosmology is interconnectedness of all elements in the universe; the spiritual manifesting in the material and human realms (Azibo 1999; Carroll 2008, 2014:258-260; Kambon 2004:79-81; Kwate 2005:224-226; Mbiti 1969:39-48). The African world view is thus holistic, representing an integrated view of the totality of human functioning embedded in a larger religiousspiritual understanding.

\section{Epistemology - Theory about knowledge}

Holism is a strong theme in the African view of knowledge. Understanding and knowledge are based on the collaboration between people, with people learning from nature and the spiritual realm. Ani (1994:102) asserted that 'the awareness of meaning of life comes from observing how the various living things appear to mesh and to provide a whole tapestry'. Nevertheless, the use of rationality and scientific reasoning are not precluded (Bakari 1997:3-4). African epistemology can thus be described as rational, spiritual and mystical (Asabere-Ameyaw \& Anamuah 2006; Cooper 2013; Emeriole et al. 2001; Fakudze 2003).

\section{Axiology - Values and ethics}

In an African world view, collectivistic values are supreme (Azibo 1992; Baldwin \& Bell 1985) and dominate in ethics and aesthetics. Human relations are thus prioritised (Carroll 2014:258) while each human being is valued for whom he or she is.

Africans' religion permeates their social and cultural life (Gyekye 1996; Mbiti 1969:1). African religious and spiritual values are not necessarily aligned with all Christian spiritual values and specifically the ideals stipulated for RCC seminarians and priests. Therefore, the main values of celibacy, poverty and obedience are emphasised in the training of RCC priests. It is recognised that RCC seminarians from Western cultures may also experience these 'countervalues' as problematic and difficult to live by. However, the focus of this article is on the African seminarians' unique experiences. Value of celibacy, poverty and obedience are explored from an African perspective next.

\section{Celibacy}

Celibacy of priests is a long tradition (Tambudzai \& Ugwuanyi 2011:79-83). In contrast, Africans value marriage, which is revered as the epicentre of African life. Mbiti (1969:133) asserted that marriage 'is the point where the departed, the living and those yet to be born meet. All the dimensions of time meet here and the whole drama of history is repeated, renewed and revitalized'. Marriage and reproduction are pivotal values in African culture. The role of a parent supersedes all other roles (Bujo 1998:99), and marriage and parenthood bestow on a person a higher status than those who are single and have no offspring. Therefore, African RCC seminarians are confronted with and are expected to subscribe to a value that is directly in opposition to their cultural scripts.

\section{Poverty}

Priests are expected to live simple and austere lifestyles refraining from redundant and material things (Optatam Totius 9; C.I.C. Can 282). Poverty as a value is a condition and essential premise of the Apostle's docility to the Spirit, making him ready to 'go forth', without a travelling bag or personal ties, following only the will of the Master (cf. Lk 9:57-62; Mk 10:17-22). The vow of poverty is almost impossible to be seen as a value and an ideal for Africans where in most of their languages, the concept poverty denotes a 'sense of wretchedness and has negative implications' (Kiaziku 2007:125). Generally, poverty is not a free choice for most Africans. The idea of a priest who has no earthly possessions leading a religious community therefore directly conflicts with the African expectation that the leader or the chief will be more affluent than his people and therefore be able to share his wealth with his people (Shorter 1999:14-15). Not only do seminarians lose status in the eyes of their communities of origin if they are poor, but they may experience emotional discomfort arising from cognitive dissonance (Festinger 1962). It is recognised that the interpretation of the vow varies between priests from religious congregations and secular diocesan priests. Priests from religious congregations do not earn a salary and are cared for by their religious congregation while Diocesan priests are supposed to earn a modest salary from their church communities and have some level of financial independence.

\section{Obedience}

For seminarians obedience to the prescriptions of scripture and RCC dogma is a given. The priests in training are also expected to unquestioningly obey the RCC's hierarchy, which includes the Pope, Bishop, Rector and other leaders (Shorter 2000:7-8). African seminarians may struggle to accept the authority of younger chosen leaders amongst themselves, because in the African cultural script, age is an important determinant of status (Kiaziku 2007:157-158; Tambudzai \& Ugwuanyi 2011:74). Seminarians are confronted with the reality that in the RCC, age is not as important as seniority in terms of the hierarchical church structure.

During their training, seminarians' global meaning systems or world views as expressed in cosmology, epistemology and fundamental values through which they understand themselves, their communities and the world are thus fundamentally challenged (Rulla, Imoda \& Ridick 1979: 145-196). Deeply held African values and principles are frequently disregarded (poverty and celibacy) or prescribed 
in a foreign format (obedience). The seminarians are thus confronted with the challenge to manage the dialectic between separation and connectedness as per Western versus African world views, 'while avoiding the undesirable outcomes of fusion and enmeshment on the one hand, or complete detachment and isolation on the other' (Lapsley \& Horton 2002:2).

\section{Problem statement and aim}

In the light of the growth of the RCC church in Africa (CSGC Report 2013:14) and the declining RCC membership numbers in Europe and North America, the need for more African RCC priests to serve the growing membership in Africa and the African diaspora (Enwerem 2011:90-105) is evident. However, the challenges African men who become part of the RCC clergy face may be daunting, especially to embrace being both an African man and a RCC priest. Such challenges have not previously been explored and described. Therefore, the aim of this research was to explore the experiences of African RCC seminarians and to generate interpretive descriptions that may inform decisions about seminary curriculums for the training of African RCC priests.

\section{Methodology}

A qualitative methodology was adopted for this interpretive descriptive research (Thorne, Kirkham \& MacDonald-Emes 1997; Thorne, Kirkham \& O'Flynn-Magee 2004:2-4), thus acknowledging the contextual and constructed nature of the experiences of the seminarians. Participants were selected purposefully and data were collected through in-depth individual semi-structured interviews (Rodham, Fox \& Doran 2015:59-71). The interpretation of findings was through the lens of concepts of African-centred psychology (Mazama 2001:393-399) aiming at generating knowledge that might inform decisions about the curriculum in seminaries that train African RCC priests.

\section{Context and participants}

Two RCC seminaries in South Africa where predominantly Western Catholic dogma and practices are upheld gave permission for the recruitment of participants. Inclusion criteria for voluntary participation were that the student had to have grown up in Africa amongst African kin and within African culture, was able to speak his local language and English, had at least completed secondary school and had to be willing to share his views openly and honestly. Sixteen students took part in the study. Six students were between the ages of 21 and 23 and 10 students were between the ages of 24 and 31. There were 10 South Africans, two Kenyans, two Zimbabweans, one Cameroonian and one person from the Democratic Republic of Congo. Seven of the participants were affiliated to diocesans and 9 to religious congregations. The participants had completed the first 3 years of philosophical studies and were in various stages of the 4 years of theological studies.

\section{Data gathering}

Ethical clearance for this study was provided by the Ethics Committee of North-West University, Vaal Campus (NWU00098-13-S8). Interviews with participants which were transcribed verbatim, were guided by questions focusing on the content of their training, how cultural issues played out and impacted on their lives during their training and their recommendations for the training of African seminarians.

The first author being an African RCC priest had a unique opportunity to establish rapport with the participants. However, this intuitive understanding of the participants' experiences also posed a challenge of which he was acutely aware. He thus meticulously made reflective notes in an attempt to continuously be aware of and to own his thoughts, needs, emotions and past experiences relating to the research phenomenon and thus to achieve what Ricoeur (1971:529562) terms distancing. A research journal was kept for noting observations about the context and surroundings of the seminarians. All notes were valuable sources of data (Tracy 2013:37).

\section{Analysis}

Various iterative cycles and levels of data analysis which focused on primary (open coding) and secondary (axial or focused) coding were conducted (Tracy 2013:183-202). Codes were combined in categories that were grouped in themes. Researchers also implemented elements of constant comparative analysis. Incidences of the same category were compared, which contributed to a more integrated description of categories and themes (Glaser 1965:436-445). Flexibly managing the dialectic between data and theory was achieved through discussions between the two authors who individually analysed the data (Thorne et al. 2004:6). Themes and sub-themes were inductively constructed from the analysed data. These themes were then related deductively to African-centred psychological concepts and constructs. The iterative process included moving between identifying and connecting words, concepts and ideas and eventually arriving at abstract principles (Devenish 2002:1-2) and useful interpretations.

\section{Quality assurance}

The research topic has been demonstrated as timely, and significant (Tracy 2013:227-249). An extended period of time (3 years) was spent in the field to acquire rich data, which were meticulously analysed by two independent coders to ensure trustworthiness (Guba 1981). Credibility was achieved by providing a complex description of concrete details and tacit knowledge of the first researcher building on crystallisation of insights extracted and formed from three data sets (interviews, research journal and reflexive notes) and feedback from participants (Tracy 2013:203-225). Thus, transferability (Creswell 1998; Grbich 2007; Lincoln \& Guba 1985) was also enhanced. 


\section{Research findings and discussions}

Experiences of seminarians varied; however, the difference was not in the essence of their experiences rather in intensity. Biographical realities that impacted their experiences were the region they came from and their affiliation. The seminarians who hailed from deep rural areas understandably experienced more intense culture shock than those from urban township areas. The different RCC affiliations traditionally have marginally different expectations for the seminarians from religious orders who take vows and for diocesan seminarians who make promises. Although no notable differences were identified in the experiences of the two groups of participants in general, the value of poverty was more problematic for priests from religious orders. In the interest of clarity, participants are therefore classified in the discussion of findings as representing either the religious group (R) or the secular diocesan group (S). Upon entering a seminary, African seminarians' step into a milieu steeped in centuries of RCC teaching, practices and rituals. From the outset, the challenge for African seminarians was to merge their African way of being-in-the-world with the philosophy and values of the RCC, which they freely chose to serve. Themes that represent their experiences are presented below.

\section{My cultural heritage is important}

All participants experienced the immersion in what for them was an alien culture as disconcerting on many levels. Although they accepted that academically they would explore new vistas of knowledge, each participant felt indignant that African philosophy did not receive enough attention in the curriculum:

'We have subjects like African philosophy and theology and I think it is helpful if one goes into these subjects with a critical mind in order to find ourselves in the bigger picture and make our lives as priests meaningful. If we do not critically deal with these subjects we may end up having [an] identity crisis, not belonging to anything. In short not much is taken into consideration as far as I am concerned.' (S1-R)

'It is only in philosophy that something of Africa is covered ... it is very superficial stuff.' (S13-S)

The need that perhaps goes beyond academic-intellectual engagement with African views is a need for being acknowledged as Africans who have a unique philosophical and cultural heritage:

'I do not think my African views have any place as far as my training is concerned. Ever since I joined I am being formed, fashioned to think, live and work like a European. There and there I can say the formation tries to integrate my views as an African ... but it does not work, it does not work at all.' (S4-R)

'In spirituality we explored briefly the issue of ancestors in relation to Christian saints. But a course in spirituality does not prove enough because I believe that there are other things that still need to be explored.' (S9-S)

Why did seminarians feel unacknowledged and misunderstood? African-centred psychology suggests that the schism between the African and Western world views may partly illuminate the reason for the participants' alienation. The data suggest that their training systematically chiselled away at their global meaning system their fundamental understanding of the world and their cherished values causing them intense discomfort and cognitive dissonance (Festinger 1962). An interesting pattern of themes were identified that shed light on the probable nuances of cognitive dissonance. There are clear intersections between the RCC world view and concomitant values of Africa. However, striking similarities were set off by stark dissimilarities. Thus, the values may superficially seem the same but in essence they are different.

\section{I want to be a good man}

Participants expressed confusion and discomfort regarding what in their experience amounted to a distortion of values held dearly in their own cultures. Discomfort with the similarity but also dissimilarity between RCC and African values of community, wealth and respect were general and recurrent themes in the experiences of most $(88 \%)$ participants.

Community is valued in Africa and in the RCC. However, what community is, is understood differently. In Africa, community is defined by blood ties and proximity (Bujo 1998:181-182). Relatives do not only share material things but perhaps more importantly they share their lives with each other in an African community (Gyekye 1996; Kiaziku 2007).

In the seminary, an alternative understanding of community is taught and lived, which is based on religious grounds (Magesa 2013a:89). Community is thus based on another kind of bloodline - that of the community in Christ. The latter excludes the former understanding, which creates distress. Unrelated people in the religious community become brothers in a comfortable environment and a wellresourced family where all needs are met but they cannot share these privileges with their blood relatives (Magesa 2013a:88-89):

'The sharing is a problem. In a community we share many things but I cannot be allowed to share with my parents or brothers and sisters who are not religious.' (S5-R)

A sense of growing disconnectedness from their family of origin and their familial and cultural sense of place was evident. Participants (62\%) expressed a sense of sadness at being disconnected, which entailed not being able to share their experiences at the seminary with relatives who inhabit a world so different from theirs that sharing their experiences was all but futile:

'My family understands very little of what I am doing. They are not involved in my studies.' (S2-R)

However, not only do their families not understand their experiences at the seminaries, their teachers and formators who are involved in their shaping and development in the 
seminaries do not seem to understand their family connectedness and the implied providing and receiving of support in the extended family, which becomes salient in situations of death:

'If someone die[s] at home, they just send me home and just give me a condolence card for example but then I am left alone to deal with the loss, no support. I am expected to detach from home!' (S13-S)

Seminarians felt caught between these conflicting views of community, which lead to feelings of guilt, inferiority, disempowerment and unhappiness. A participant poignantly expressed his very difficult position as the eldest child of an orphaned family. He was striving to fulfil a higher calling; he was working hard to grow spiritually to serve the community but:

'from their [my siblings] side, I am a very bad person. A brother who has abandoned them, they do not understand. I am taken care of here and for them they have no one.' (S10-S)

Intuitively, participants knew that their training would eventually alienate them from their cultural and familial roots:

'Africans in the hierarchy have been trained in the American ways and are even more American than Americans themselves. It is a problem because I am an African but will be fashioned in a way that I have no way but to think like an American.' (S4-R)

Wealth (albeit defined differently) is valued and admired as worth striving for by both the Africans and the RCC. But as in the understanding of community, there is a marked difference in what wealth is understood to be. Africans value social connectedness as a form of wealth. Amongst Africans, individual well-being and indeed survival depends on the well-being of the whole community or clan (Bujo 1998:71-76); therefore, a person's place in and social relationships with family and community are paramount. The social bonds are not dominated by material wealth, rather by blood relationships. Material wealth, however, does provide status and is admired but it is not in oversupply. The individual is expected to contribute to his community by being responsible, reliable and available but also if at all possible by contributing to the material needs of the community.

In the seminary, an alternative wealth is highly regarded and nurtured - spiritual wealth and wisdom (Shorter 1999: 24-25), which for seminarians includes non-attachment to material things (the vow of poverty). Their knowledge and spiritual wealth are to enable them to fill a new social position in a new religious community that is expected to financially provide for them. However, in the interviews with seminarians it became clear that Africans find the principle of spiritual wealth in opposition to material wealth very foreign and difficult to grasp. The African seminarian leaves his kin behind to live in the seminary where all material needs are met. Comfortable lodging, enough nutritious food, clothing, medical care and study opportunities are provided. However, nothing belongs to the seminarian. For an African man, this sometimes creates unbearable dissonance. While he has his every need met, his family at home may be starving or be in need of financial support to care for children or the sickly. He is privileged possibly beyond his kin's imagination but personally has no material possessions to contribute to his community of origin:

'Sometimes I hear from home that someone is sick; there is need for this and that. I find myself not having means to help and this makes me feel a sense of helplessness.' (S1-R)

'Since I started training I have gone home four times. I have found serious problems and the family including my parents expect me to help. It is very difficult!' (S3-R)

The value conflict led one participant to bluntly conclude:

'The issue of $[$ the $]$ vow of poverty and sharing is not practical; this vow of poverty is not African. The thing is not practical especially in an African context.' (S5-R)

Although the vow of poverty is a core value for RCC seminarians and priests, the power of money within the RCC was mentioned by $69 \%$ of the participants. Their perception was that money and its sources subtly and openly dictate decisions and policies in the RCC. Money equals power - the power of privileging one world view above the other. As Europe and the Americas form the powerbase of almost all the International Missionary Institutes (Magesa 2013a:88), the Western world view is seen to be privileged. This privileged position of Western ways according to a portion of participants is so powerful and alluring that some highranking African priests are perceived to betray their own African roots as they climb the ladder of success:

'But another frustration is Africans who are in charge. When we are not in charge, some advocate for change but when they get there, they become worse than the Europeans against their own African bothers.' (S1-R)

Worthiness of respect in both African and RCC communities could practically be distilled to how the individual conducts himself in service of the community. Africans serve their community by ensuring that their bloodline lives on. Not procreating is associated with damaging the family lineage (Bujo 1998:94-95; Kirwen 2005:133-148). Thus, a man without children loses status and respect in the community because he does not serve his community according to its expectations. However, the vow of celibacy prohibits procreation and thus effectively diminishes the status of the seminarians in their communities of origin:

'a man is to be a man and one of the things is to be married, get children and continue the surname, continue the clan name.' (S10-S)

'unmarried life is a problem ... As a priest you may be allowed to sit at the place for men, though they know that you are not a man.' (S2-R)

The rationale for a priest to live a celibate life is that he will be able to direct all his attention to spiritual and practical matters within the RCC. He will be unencumbered by family concerns and free to move to different places for missionary and 
pastoral activities. The better he is able to do this, the more he is respected within the church. Celibacy from the RCC's perspective is a free choice, a higher value and a sacrifice for the greater good (Kiaziku 2007; Shorter 1998:12-14).

The necessity of constantly having to adjust their cultural framework of morality and role expectations for them as men left the participants in psychological disharmony.

\section{I don't dare disclose my deepest African being}

All seminary activities are aimed at developing a well-rounded priest. Other than the academic programme, daily religious practices and rituals that contribute to this end, as well the specialised skills of spiritual directors and psychologists, are employed to nurture holistic development. A major component of the personal development of seminarians is spiritual growth, which is nurtured by the tradition of having a spiritual director who may be a man or a woman. Spiritual direction in the RCC presupposes an open relationship and involves guidance by a spiritual mentor, it is 'concerned with one's relationship with God, with the self, with other people and with nature' (Michael 2004:8) thus focussing on the unfolding of the individuals identity (Mosha 2013:105-114). This ideal coincides with views held in Africa where all life is understood to be spiritual; all aspects of creation and life are sacred and complement each other (Magesa 2013b:167-176). In traditional African societies, the younger generation is coached and guided in their holistic development by older people of their own gender who are respected cultural examples.

Spiritual direction and formation are ingrained practices in the RCC seminarians' training. From the perspective of the RCC, a good spiritual director and formator will have certain psychospiritual characteristics and specific skills in providing spiritual direction, in order to guide any person in need. However, this rationale proves to be of limited value when there is such a clear cultural divide as previously described. If the deeply held cultural beliefs are not respected, the potentially significant contribution of spiritual direction and formation may be compromised. Seminarians (63\%) expressed disbelief that they would be understood by their spiritual directors and formators:

'formators (a decision maker) also should have knowledge of the students' cultural belief systems and practices.' (S5-R)

Apart from feeling misunderstood because of the cultural divide, some participants also feared that what was disclosed to their spiritual director may be held against them:

'Obviously, you cannot be open. How can I be open to the spiritual director, because when you do, it goes against you, it goes to your report. We live in the world of fear here in the seminary.' (S10)

African cultural taboos prohibit sharing sensitive issues between genders and even between generations. Having an elderly lady as spiritual director was an affront to one seminarian:
'For me spiritual direction is a problem. It is worse sometimes we are even given women. How can I share with a woman? You are given a gogo (grandmother) who is 75 years old and you are only 20 years old. Your worldviews are not the same and most of them are white.' (S10-S)

The role of the psychologist was perceived negatively by a majority $(81 \%)$ of the participants. The power of the psychologist whom they perceived as the one who tested, evaluated and weighed them was feared. Participants' emotionally described their suspicion and distrust of psychologists in the seminaries. Being sent for psychological evaluation was perceived to be a sign that something was wrong with them. Their perception was that if one was referred to the psychologist it meant imminent elimination from training:

'The psychological report is useless because it is not used to help me. It is not used for formation, [rather for] elimination!' (S10-S)

'Psychology [the psychologist] is used as an elimination tool to kick people out and its role is not clear. No one tells you that this is how it will help you. Students then become suspicious and afraid of psychology in the institution.' (S1-R)

'you are sent to see psychologist when they think that something is wrong with you. It is a well-known fact that you are not coming back to seminary next year. The psychologists are not brought to us to help but to find a way of getting us out.' (S16-S)

Seminarians seem to be uncertain about the contribution of psychologists. This seems to go hand in hand with distrust and fear. Distrust of psychological services rendered by employers is however not unique to seminaries (Greenberg \& Baron 2003) and may mainly be a result of the fear that personal information will not be kept confidential.

\section{Where do I belong?}

The difficulties seminarians experience frequently culminate in a sense of marginality - the more they embrace Roman Catholicism, the more they felt relegated to the periphery of their family and community of origin. The dilemma while in training was that they felt neither part of the inner circle of the church nor of their families and communities. They experienced themselves as marginalised. They felt they inhabited an in-between position (Lee 1995), which forced them to resort to just doing what was expected without fully being committed to or identifying with their formation as future priests:

'... sometimes you just wear mask or conform out of fear of offending elders or being kick[ed] out of the institute.' (S9-S)

'... in the seminary ... you hear people saying just do whatever they want if you want to survive. Some will tell you that they are sent simply to do whatever they are told to do, no questioning. I think, father, seminarians are just wearing masks.' (S16-S)

'Because the pressure is strong in the seminary people wear mask[s].' (S12)

Interestingly these participants conveyed the belief that being true to themselves as Africans could not be aligned 
with being true to the Church. The challenge experienced by the participating African RCC seminarians could be described as a struggle to integrate African and Western world views and develop an identity that enables them to live and work in both the RCC and African communities simultaneously. A position that Lee (1995:63) described as being 'in-beyond', which requires the seminarian to be honest and true to himself as African and RCC seminarians and willing to openly communicate with and accept others.

\section{Conclusion}

Burke's (2001:9-17) caution that Western churches need to find relevance in Africa is also applicable to the churches' training of African clergy. Findings indicate that more than a decade later this challenge has not been met. Seminary formation seems to be overwhelming for the participants who seemed to be in an on-going struggle to appreciate and affirm their own culture and personal cultural identities as they progressed through academic and spiritual development. Developmentally, the seminarians have the challenge to progress from an egocentric to an ethnocentric and thereafter a world-centric level of development (Wilber 2000) cognitively, morally, emotionally and spiritually.

The findings indicate various factors that might inform the curriculum of RCC seminaries that train African priests.

Findings point to two overarching issues. Firstly, 'us and them' thinking amongst African seminarians - us Africans who come from a specific philosophical and cultural background and them who teach train and form us but who do not fundamentally understand us. A concern is that these discourses and beliefs become the lived truth of the seminarians. Such thinking can taint perceptions and interpretations of their experiences in the seminaries. And secondly, that seminarians make vows and promises that may seem cognitively acceptable but that are contrary to cultural and emotional needs. Some suggestions for mitigating these difficulties are discussed in the following paragraphs.

Taking African philosophy, culture and spirituality more seriously and affording these more attention would possibly contribute to the seminarian's self-understanding and acceptance. Sensitive, respectful and well-informed interactions between the teacher of African philosophy and the African seminarians might provide a platform for mastering and grasping other philosophies, thus scaffolding their learning (Sanders \& Welk 2005; Van Der Stuyf 2002). This could also facilitate the process of cultural identification followed by transcendence thus creating a foundation for their socio-emotional adjustment and identity (Kins, Soenens \& Beyers 2012:1099). Including the candidates' families as much as possible in their training by disseminating information, having open days and other activities may also contribute to seminarians smoother transition into the seminaries and their well-being in general.
Regarding spiritual formation, the decision makers may need to be more culturally aware and sensitive in their appointment of spiritual directors of African seminarians. This seems necessary not because some formators are less skilled but because of the seminarians' perception of cultural dissimilarity and connected fears of not being understood and being judged. That the relationship with the spiritual director is sacrosanct probably needs to be reiterated frequently as this is the relationship that will most likely enable self-reflection, healing and growth for the seminarian. Where possible, it would be best to have Africans involved in the formation of African priests

It would further be beneficial to openly clarify the role of the psychologist in the training and formation of the seminarians. This clarification may also initiate a discussion of the values of confidentiality and their limitations in the practice of the psychologist in the seminary. Psychologists in the institutes probably need to carefully consider psychotherapeutic dyads such as Western expressions and words used that are not understood by African counselees and the uncritical use of psychotherapeutic approaches that are fundamentally rooted in Western belief systems of individuality (Bojuwoye 2013:74-78). It would be wise to ensure that there is a clear understanding of the place and function of psychology as discipline included in their curriculum and the role of the psychologist initially to screen and select candidates and later to act as therapist (Rulla et al. 1979:162-163).

A limitation of the research is that only the initial motivations of seminarians to become priests were probed. These motivations mostly included wanting to be like an influential priest or to be educated. We did not explore the changes in the motivation or calling, which may have contributed to a better understanding of their experiences in the seminary.

\section{Acknowledgements Competing interests}

The authors declare that they have no financial or personal relationships which may have inappropriately influenced them in writing this article.

\section{Author(s) contributions}

All authors equally contributed to the research and writing of this article.

\section{References}

Ani, M. 994. Yurugu, an African-centred critique of European cultural thought and behaviour, Africa World Press, Asmara.

Asabere-Ameyaw, A. \& Anamuah, J., 2006, 'Taboo systems and rituals. A simple technology for environmental resource management: The case of the Dagaaba and Mamprusis of Ghana', Journal of Development Alternatives and Area Studies, 25(1-2), 104-115.

Azibo, D., 1992, 'Articulating the distinction between Black studies and the study of Blacks: The fundamental role of culture and the African-centered worldview', The Afrocentric Scholar 1(1), 64-97.

Azibo, D.A., 1999, 'Afrocentric conceptualizing as the pathway to African liberation', International Journal of African Studies 5, 1-33. 
Bakari, R.S., 1997, 'Epistemology from an Afrocentric perspective: Enhancing Black students' consciousness through an Afrocentric way of knowing', Different Perspectives on Majority Rules 20, viewed n.d., from http://digitalcommons.unl. Perspectives on

Baldwin, J.A. \& Bell, Y.R., 1985, 'The African self-consciousness scale: An Africentric personality questionnaire', The Western Journal of Black Studies 9(2), 61-68.

Bojuwoye, O., 2013, 'Integrating principles underlying ancestral spirits belief in counselling and psychotherapy', Ife PsychologIA 21(1), 74-88.

Bujo, B., 1998, The ethical dimension of community: The African model and the dialogue between North and South, Paulines Publications Africa, Nairobi.

Burke, J., 2001, Towards the inculturation of religious life in Africa: A case study and reflection guide, 2nd edn., Paulines Publications Africa, Nairobi.

Carroll, K.K., 2008, 'Africana studies and research methodology: Revisiting the centrality of the African worldview in African studies research and scholarship', Journal of Pan African Studies 2(2), 4-27.

Carroll, K.K. 2012, 'A genealogical review of the worldview concept and framework in Africana studies related theory and research', in J.L. Conyers (ed.), African American consciousness: Past and present, pp. 23-46, Transaction, New American

Carroll, K.K., 2014, 'An introduction to African-centred sociology: Worldview, epistemology, and social theory', Critical Sociology 40(2), 257-270. https://doi. epistemology, and social theory',
org $/ 10.1177 / 0896920512452022$

Centre for the Study of Global Christianity (CSGC), 2013, 'Christianity in its global context, 1970-2020: Society, religion, and mission', in Gordon-Conwell Theological Seminary, 22 June, viewed 26 February 2016, from http://wwwgordonconwell. com/netcommunity/CSGCResources/ChristianityinitsGlobalContext.pdf

Cooper, S., 2013, 'Africanizing South Africa psychology', Journal of Black Psychology 39(3), 212-222. https://doi.org/10.1177/0095798413478070

Corieden, J.A., Green, T.J. \& Heintschel, D.E. (eds.), 1985, The code of Canon Law, Geoffrey Chapman, London.

Creswell, J.W., 1998, Qualitative inquiry and research design: Choosing among five traditions, Sage, Thousand Oaks, CA.

Devenish, S., 2002, 'An applied method for undertaking phenomenological explication of interview transcripts', The Indo-Pacific Journal of Phenomenology 2(1), 1-20, https://doi.org/10.1080/20797222.2002.11433873

Ellis, J., 1965, 'Short history of seminary education I and II', in J. Lee \& L. Putz (eds.) Seminary education in a time of change, Fides, Notre Dame, IN

Emeriole, H., Munyadzwe, T., Ntingana, C. \& Mosimakoko-Mosalakgoko, T., 2001 'Rationalisation and science. Instructional implications of some superstitious beliefs about natural phenomena in Botswana', African Journal of Research in Mathematics and Science Education 5, 65-84.

Enwerem, I.M., 2011, 'African Catholicism and the diaspora phenomenon: A sociopolitical analysis of African priests in the diaspora', Journal of Global Initiatives: Policy, Pedagogy, Perspective 6(1), article 5, viewed 25 May 2015, from http:// Policy, Pedagogy, Perspective $6(1)$, article 5,
digitalcommons. kennesaw.edu/jgi/vol6/iss $1 / 5$

Fakudze, C., 2003, 'The nature of worldviews held by Swazi-High school students', in M. Ogunniyi \& K. Rockford (eds.), The pursuit of excellence in science and mathematics education, pp. 58-62, School of Science and Mathematics Education, Western Cape.

Festinger, L., 1962, A theory of cognitive dissonance, Stanford University Press, Stanford, CA.

Glaser, B.G., 1965, 'The constant comparative method of qualitative analysis', Social Problems 12(4), 436-445. https://doi.org/10.2307/798843

Grbich, C., 2007, Qualitative data analysis: An introduction, Sage Publications, London.

Greenberg, J. \& Baron, R.A., 2003, Behaviour in organizations: Understanding and managing the human side of work, 8th edn., Pearson Education, New Jersey.

Guba, E.G., 1981, 'Criteria for assessing the trustworthiness of naturalistic inquiries', Educational Communication and Technology Journal 29, 75-91.

Gyekye, K., 1996, African cultural values: An introduction, Sankofa Publishing Company, Accra.

Jamison, D. \& Carroll, K.K., 2014, 'A critical review and analysis of the state, scope and direction of African-centered psychology from 2000-2010', Western Journal of Black Studies 38(2), 98-107.

Kambon, K., 2004, 'The worldviews paradigm as the conceptual framework for African/Black psychology', in R. Jones (ed.), Black psychology, pp. 73-92, Cobb \& Henry, Hampton.
Kiaziku, V.C., 2007, Consecrated life in Bantu Africa, Paulines Publications Africa, Nairobi.

Kins, E., Soenens, B. \& Beyers, W., 2012, 'Parental psychological control and dysfunctional separation-individuation: A tale of two different dynamics', Journal of Adolescence 35, 1099-1109. https://doi.org/10.1016/j.adolescence.2012. 02.017

Kirwen, M.C. (ed.), 2005, African cultural knowledge: Themes and embedded beliefs, MIAS Books, Nairobi.

Kwate, N.O.A., 2005, 'The heresy of African-centered psychology', Journal of Medical Humanities 26(4), 215-235, https://doi.org/10.1007/s10912-005-7698

Lapsley, D.K. \& Horton, M.D., 2002, 'The construct validity of pathology of separationindividuation (PATHSEP)', 9th Biennial Meeting of the Society for Research on Adolescence, New Orleans, LA.

Lee, J.Y., 1995, Marginality, Augsburg Fortress, Minneapolis, MN.

Lincoln, Y.S. \& Guba, E.G., 1985, Naturalistic inquiry, Sage Publications, Beverly Hills, CA.

Magesa, L., 2013a, 'The future of international missionary institutes in Africa', SODOS Bulletin (SI) 45(3), 80-90.

Magesa, L., 2013b, What is not sacred? African spirituality, Maryknoll, New York.

Makwe, E.R., 1985, 'Western and indigenous psychiatric help-seeking in an urban African population', Unpublished master's dissertation, University of the Witwatersrand, Johannesburg, South Africa.

Mazama, A., 2001, 'The Afrocentric paradigm: Contours and definitions', Journal of Black Studies 34(4), 387-405. https://doi.org/10.1177/002193470103100401

Mbiti, J.S., 1969, African religions and philosophy, Heinemann, Johannesburg, South Africa.

Michael, C.P., 2004, An introduction to spiritual direction: A psychological approach for directors and directees, Paulist Press, New York.

Mosha, R.S., 2013, 'Spiritual direction and African indigenous spirituality', The Way 52(3), 105-114.

Myers, L.J., 1988, Understanding an Afrocentric world view: Introduction to an optimal psychology, Kendal/Hunt, Dubuque, IA

Nsamenang, A.B., 2007, 'Origins and development of scientific psychology in Afrique Noire', in M.J. Stevens \& D. Wedding (eds.), Psychology: IUPsyS global resource, Psychology Press, London.

Ricoeur, P., 1971, 'The model of the text: Meaningful action considered as a text', Social Research 38(3), 529-562.

Rodham, K., Fox, F. \& Doran, N., 2015, 'Exploring analytical trustworthiness and the process of reaching consensus in interpretative phenomenological analysis: Lost in transcription', International Journal of Social Research 18(1), 59-71. https://doi. org/10.1080/13645579.2013.852368

Rowe, T.D., 2016, 'Black psychology and the African Psychology Institute', Journal of Black Psychology 39(3), 269-271. https://doi.org/10.1177/0095798413480678

Rulla, L.M., Imoda, F. \& Ridick, J., 1979, Psychological structure and vocation: A study of the motivations for entering and leaving the religious life, Villa Books, Dublin, of the moti
Ireland.

Sanders, D. \& Welk, D.S., 2005, 'Strategies to scaffold student learning: Applying Vygotsky's zone of proximal development', Nurse Educator 30(5), 203-207. https://doi.org/10.1097/00006223-200509000-00007

Shorter, A., 1998, Celibacy and culture, Paulines Publications Africa, Nairobi.

Shorter, A., 1999, Religious poverty in Africa, Paulines Publications Africa, Nairobi.

Shorter, A., 2000, Religious obedience in Africa, Paulines Publications Africa, Nairobi.

Tambudzai, I.A. \& Ugwuanyi, C.C. (eds.), 2011, The priestly ministry in Africa: Reflections by seminarians and priests, Paulines Publications Africa, Nairobi.

Thorne, S., Kirkham, S.R. \& MacDonald-Emes, J., 1997, 'Interpretive description: A non-categorical qualitative alternative for developing nursing knowledge', Research in Nursing \& Health 2, 167-177.

Thorne, S., Kirkham, S.R. \& O'Flynn-Magee, K., 2004, 'The analytical challenge in interpretive description', International Journal of Qualitative Methods 3(1), 1-11.

Tracy, S.J., 2013, Qualitative research methods: Collecting evidence, crafting analysis, communicating impact, Wiley-Blackwell, Malden, MA.

Van Der Stuyf, R.R., 2002, 'Scaffolding as a teaching strategy', Adolescent Learning and Development 52(3), 5-18.

Wilber, K., 2000, Integral psychology: Consciousness, spirit, psychology, therapy, Shambhala Publications, Boulder, CO. 